\title{
ПІДВИЩЕННЯ ЕНЕРГЕТИЧНОЇ ЕФЕКТИВНОСТІ БІОГАЗОВИХ РЕАКТОРІВ
}

\author{
В.П. Клюс, канд. техн. наук, Г.О. Четверик, канд. техн. наук, 3.В. Маслюкова
}

Інститут відновлюваної енергетики НАН України, 02094, вул. Гната Хоткевича, 20А м. Київ, Україна.

Для невеликих фермерських господарств актуальним є переробка органічних відходів в енергоефективних біогазових реакторах. Метою роботи є підвищення енергоефективності біогазових реакторів. Розроблено дві нові конструкиії біогазового реактора, які відрізняються від відомих конструкиій тим, ще в них перетворення поступального руху газгольдера в обертання перемішуючого пристрою забезпечується за рахунок використання механізму із зубчасто-рейковою передачею та механізму з канатною тягою відповідно. При изому для перемішування субстрату використовується вироблений біогаз, щзо накопичується в газгольдері мокрого типу. Показано, що енергоефективність біогазових реакторів з мокрим газгольдером підвищується шляхом зниження енергетичних витрат на підтримку процесу бродіння. Запропоновані конструкиії реакторів можна використовувати під час проектування нових та удосконалення існуючих біогазових реакторів з мокрим газгольдером. Проведено експеримент з анаеробного бродіння коров'ячого гною, до якого вносили біовугілля, отримане способом часткової газифікачї стебел сонямнику та деревної тріски. Визначено, щуо вихід біогазу підвищився на 7,9-14,6 \% $і$ вихід метану підвищився на 6,7-11,4\% під час бродіння субстратів, до яких вносили біовугілля у порівнянні з контрольним субстратом. Визначено максимальну інтенсивність виходу біогазу та тривалість лаг-фази під час бродіння коров'ячого гною, у тому числі й із внесеним до коров 'ячого гною біовугіллям. Показано, щчо енергоефективність біогазових реакторів підвишується шляхом інтенсифікаиї процесу бродіння. Розглянуті у цій роботі види біовугілля пропонується вносити до традиційних субстратів з метою інтенсифікації процесу бродіння. Бібл. 13, рис. 5.

Ключові слова: біореактор, біогаз, іммобілізачія, перемімуючий пристрій, біовугілля.

\section{INCREASING OF ENERGY EFFECTIVE OF BIOGAS REACTORS}

V. Kliys, candidate of technical science, H. Chetveryk, candidate of technical science, Z. Masliukova

Institute of Renewable Energy of the National Academy of Sciences of Ukraine, 02094, 20A Hnata Khotkevycha St., Kyiv, Ukraine.

For small farms the processing of organic waste in energy efficient biogas reactors is relevant. The purpose of the work is to increase the energy efficiency of biogas reactors. Two novel designs of biogas reactor have been developed which differ from the known designs in that they transform the translational motion of the gasholder into the rotation of the mixing device by using a gearrack mechanism and a cable-thrust mechanism respectively. In this case the biogas accumulated in the gasholder is used to mix the substrate. It has been shown that the energy efficiency of biogas reactors with wet gasholders is enhanced by reducing energy to support the digestion process. The proposed reactor designs can be used to design new and refine existing wet gasholders biogas reactors. An anaerobic digestion of cow manure using biochar was carried out obtained by the method of partial gasification of sunflower stems and wood chips. It has been determined that biogas yield increased by 7.9-14.6\% and methane output increased by 6.7$11.4 \%$ during digestion of substrates that were introduced with biochar compared to the control substrate. The maximum intensity of biogas output and the duration of the lag phase during the digestion of the cow manure including the biochar introduced into the cow manure were determined. It has been shown that the energy efficiency of biogas reactors with wet gasholders is enhanced by intensification of the digestion process. The proposed biochar can be used to intensify the digestion process. Ref. 13, fig. 5 .

Keywords: bioreactor, biogas, immobilization, stirred device, biochar.

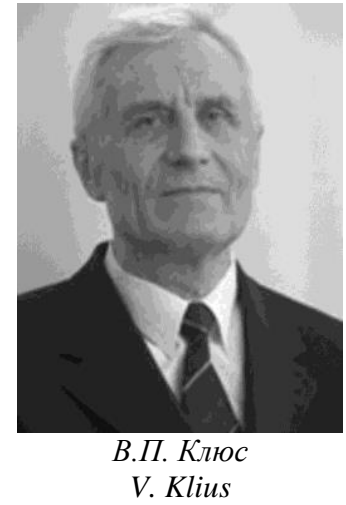

Відомості про автора: працює в Інституті відновлюваної енергетики НАН України, зав. відділом відновлюваних органічних енергоносіїв, старший науковий співробітник. Кандидат технічних наук (1980 рік).

Наукова сфера: біоенергетика, газифікація біомаси, переробка органічних відходів. Публікації: 102 наукових публікацій, у тому числі 30 патентів.

ORCID: 0000-0001-8536-3211

Контакти: тел./факс: +38-044-206-28-09

e-mail: biomassa@ukr.net
Author information: Institute of Renewable Energy of NAS of Ukraine, head of bioenergy department, senior researcher. PhD since 1980 year.

Research area: bioenergy, gasification of biomass, organic waste utilization.

Publications: 102 scientific publications, including 30 patents.

ORCID: 0000-0001-8536-3211

Contacts: tel./fax: +38-044-206-28-09

e-mail: biomassa@ukr.net 


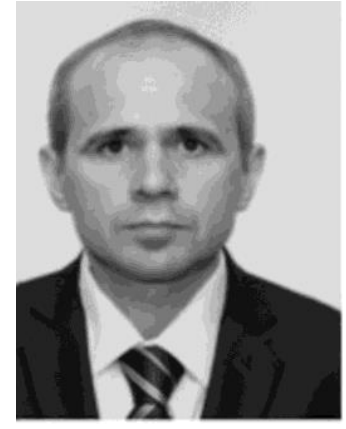

Г.О. Четверик H. Chetveryk

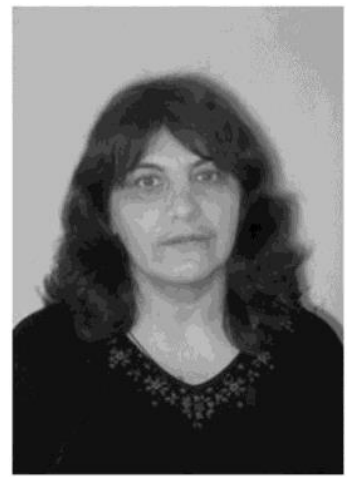

Відомості про автора: працює в Інституті відновлюваної енергетики НАН України, науковий співробітник.

Наукова сфера: біогаз, переробка органічних відходів.

Публікації: 55 наукових публікацій, у тому числі 1 патент.

ORCID: 0000-0002-4180-7930

Контакти: тел./факс: +38-044-206-28-09

e-mail: biomassa@ukr.net
Author information: Institute of Renewable Energy of NAS of Ukraine, researcher.

Research area: biogas, organic waste utilization.

Publications: 44 scientific publications, including 3 patents.

ORCID: 0000-0001-9398-1968

Contacts: tel./fax: +38-044-206-28-09

e-mail: biomassa@ukr.net

3.В. Маслюкова

Z. Masliukova

Author information: Institute of Renewable Energy of NAS of Ukraine, researcher.

Research area: biogas, organic waste utilization.

Publications: 55 scientific publications, including 1 patent.

ORCID: 0000-0002-4180-7930

Contacts: tel./fax: +38-044-206-28-09

e-mail: biomassa@ukr.net

Перелік використаних позначень та скорочень:

$\mathrm{P}$ - біогазовий потенціал субстрату, дм³/г СОР;

$\mathrm{I}_{\max }$ - максимальна інтенсивність виходу біогазу, дм³/г СОР·добу;

$\mathrm{L}$ - тривалість лаг-фази, доба;

$\tau$ - час бродіння, доба.

Вступ. Стаття присвячена створенню енергоефективних біогазових реакторів невеликого об’єму. Одним із типів газгольдерів, яких використовують в біогазових реакторах $\epsilon$ газгольдер мокрого типу. Цей газгольдер має форму купола та плаває над субстратом, що присутній в реакторі.

В роботах $[1,2]$ наведені особливості та умови використання реакторів з мокрим газгольдером. Л. Сассе обгрунтував, що об'єм реакторів 3 мокрим газгольдером не має перевищувати 40-50 $\mathrm{M}^{3} 3$ урахуванням виготовлення, транспортування та експлуатації таких реакторів [1]. В Індії біогазові реактори 3 мокрим газгольдером мають об'єм 3-85 м³ [3]. Біогазові установки 3 мокрим газгольдером широко використовують в регіонах 3 теплим кліматом, наприклад в Індії, Китаї, Пакистані [4]. Такі установки, в основному, не мають систем перемішування та підігрівання субстрату. В даній роботі пропонується розробити таку конструкцію біогазового реактора 3 мокрим газгольдером, в якій для перемішування субстрату можна використовувати вироблений біогаз.

Для інтенсифікації процесу бродіння як іммобілізатор та адсорбент використовують біовугілля $[5,6]$. Внесення біовугілля в реактор має позитивний ефект для таких видів субстратів, під час бродіння яких утворюється значна кількість амонійного азоту, що інгібує анаеробне бродіння. Амонійний азот адсорбується на поверхні біовугілля і таким чином знижується ступінь інгібування [7-10].

Однак, у роботі [11] було показано, що після внесення бамбукового біовугілля до субстрату кількість метаногенних мікроорганізмів на твердій поверхні біовугілля було дуже низьким, а вихід біогазу не збільшився. Отже позитивний ефект від внесення біовугілля залежить в першу чергу від виду біовугілля.

Біовугілля має такі ж властивості як і активоване вугілля, але його отримання значно дешевше. У відділі відновлюваних органічних енергоносіїв НАН України проводяться дослідження по отриманню біовугілля із стебел соняшнику, деревної тріски та інших видів сировини способом часткової газифікації. В даній роботі пропонується дослідити як впливає на вихід біогазу внесення різних видів біовугілля до субстрату.

Мета та завдання досліджень. Метою роботи $\epsilon$ підвищення енергетичної ефективності біогазових реакторів шляхом зниження енергетич- 
них витрат на підтримання процесу бродіння i шляхом інтенсифікації процесу бродіння. Для зниження енергетичних витрат на підтримання процесу бродіння поставлено завдання розробки конструкції реактора, в якому для перемішування субстрату використовується вироблений біогаз. Для інтенсифікації процесу бродіння поставлено завдання експериментального дослідження виходу біогазу залежно від виду біовугілля, що вносилось до субстрату.

Біореактор, в якому використовусться механізм із зубчасто-рейковою передачею. Розроблено нову конструкцію реактора 3 мокрим газгольдером, рис. 1.

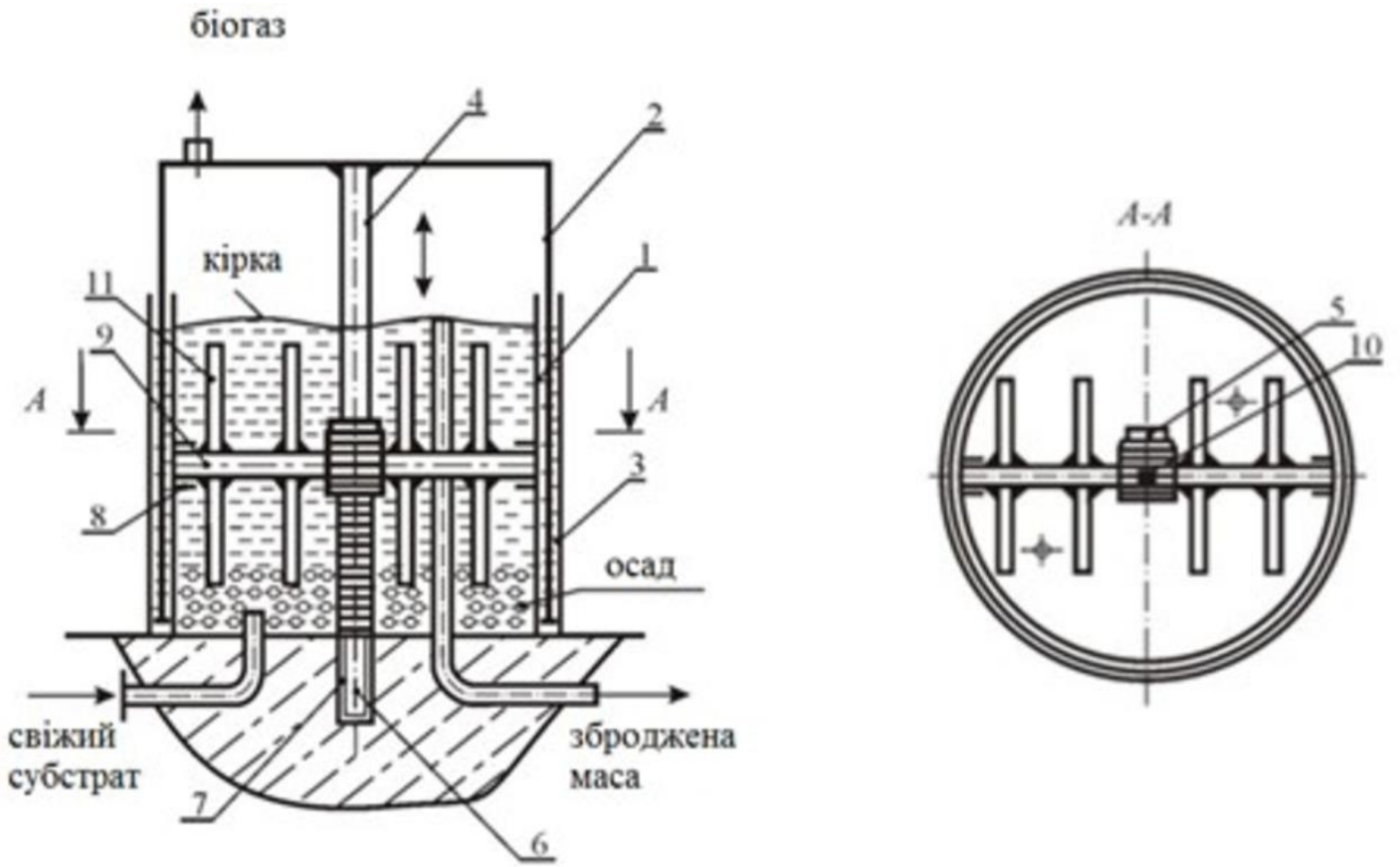

Рис. 1. Біореактор та механізм із зубчасто-рейковою передачею:

1 -корпус, 2 - газовий колокол, 3 - кільцева камера, 4- тяга, 5-зубчаста рейка, 6-направляюча, 7 -паз, 8-опори, 9-вал, 10-шестерня, 11 -лопаті.

Fig. 1. Bioreactor and a gear-rack mechanism:

1 - body, 2 - gas bell, 3 - annular chamber, 4 -thrust, 5 - toothed rack, 6 - guide, 7 - groove, 8 - bearings, 9 - shaft, 10 - gear, 11 - blades.

Перемішуючий пристрій працює наступним чином. Всередині реактора знаходиться вал з лопатями і шестернею, яка входить в зачеплення з зубчастою рейкою. По мірі виділення біогазу, колокол газгольдера переміщується вгору й тягне за собою зубчасту рейку. Вал 3 лопатями починає обертатись, внаслідок чого перемішується верхній шар субстрату та осад внизу реактора. При відборі біогазу із реактора, колокол опускається вниз і вал $з$ лопатями обертається в іншу сторону.

Отже, для роботи перемішуючого пристрою використовується біогаз, що знаходиться в газгольдері. Поставлене завдання було досягнуто за рахунок використання механізму із застосуванням зубчасто-рейкової передачі, яка поступальний рух газгольдера перетворює в обертання пе- ремішуючого пристрою.

Таким чином розроблено нову конструкцію біореактора, яка відрізняється від відомих конструкцій тим, що перетворювання поступального руху газгольдера в обертання перемішуючого пристрою забезпечується за рахунок механізму із зубчасто-рейковою передачею.

За рахунок економії енергетичних витрат на перемішування субстрату знижуються енергетичні витрати на підтримання процесу бродіння. Це означає, що енергетична ефективність перетворення органічних речовин в біогаз підвищується.

Біореактор, в якому використовується механізм із канатною тягою. В наступній конструкції біореактора, рис. 2, для обертання перемішуючого пристрою було запропоновано використати передачу з канатною тягою. 

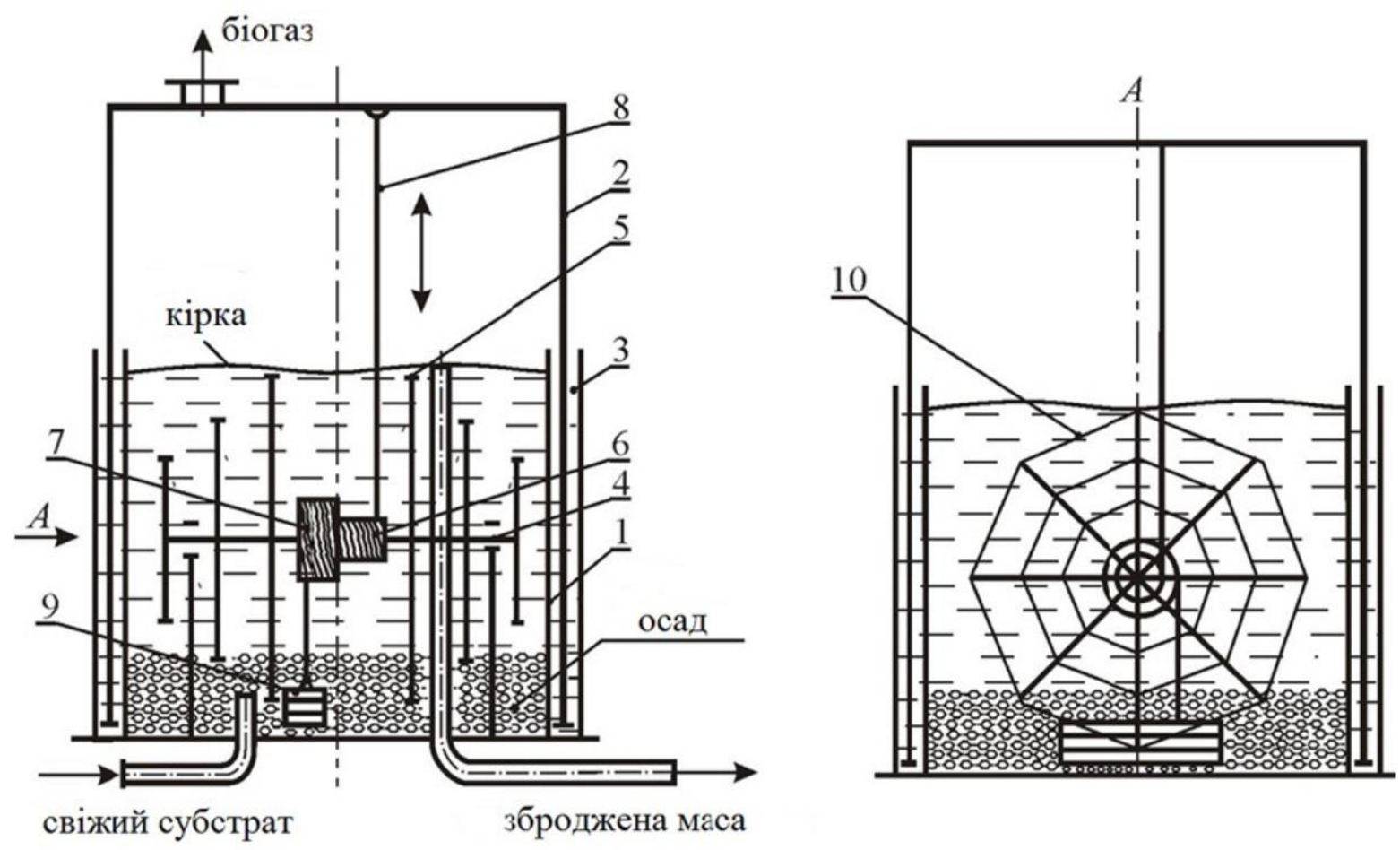

Рис. 2. Біореактор та механізм із канатною тягою:

1 - корпус, 2 - газовий колокол, 3 - кільцева камера, 4 - вал, 5 -лопаті, 6-барабан малого діаметру, 7 - барабан великого діаметру, 8 - канат, 9 - противага, 10 - поліамідні стрічки.

Fig. 2. Bioreactor and a cable-thrust mechanism:

1 - body, 2 - gas bell, 3 - annular chamber, 4 - shaft, 5 - blades, 6 - small diameter drum,

7 - large diameter drum, 8 -rope, 9 - counterweight, 10 - polyamide tapes.

Всередині реактора знаходиться вал з лопатями у вигляді окремих спиць, які з'єднуються між собою за допомогою стрічок із синтетичного матеріалу. На стрічках між лопатями закріплюються колонії бактерій, які не вимиваються під час зливу субстрату. На валу розміщені два канатних барабана. Барабан меншого діаметру через канат з'єднаний з колоколом газгольдера, а барабан більшого діаметру - 3 противагою. Обертання валу з лопатями відбувається в результаті поступального руху колокола газгольдера. Канатна передача, на відміну від зубчасто-рейкової більш надійна оскільки вона не втрачає працездатність за великих люфтів колокола.

Використання канатної тяги та горизонтального валу з лопатями дає змогу для перемішування субстрату використати підйомну силу газгольдера, яку створює тиск біогазу. Перемішування субстрату є постійним у часі, автоматичним.

Таким чином розроблено нову конструкцію біореактора, яка відрізняється від відомих конс- трукцій тим, що перетворювання поступального руху газгольдера в обертання перемішуючого пристрою забезпечується за рахунок механізму із канатною тягою.

За рахунок економії енергетичних витрат на перемішування субстрату знижуються енергетичні витрати на підтримання процесу бродіння. Це означає, що енергетична ефективність перетворення органічних речовин в біогаз підвищується.

Інтенсифікація процесу бродіння. Проведено експеримент, в якому було показано як у присутності біовугілля підвищується вихід біогазу під час переробки коров'ячого гною. Біовугілля було отримано способом часткової газифікації із стебел соняшнику та деревної тріски.

Метою проведення цього експерименту було дослідження виходу і складу біогазу залежно від виду біовугілля, яке вносили до субстрату.

Для проведення експерименту була створена біогазова лабораторна установка. Схему і фото установки показано на рис 3. 

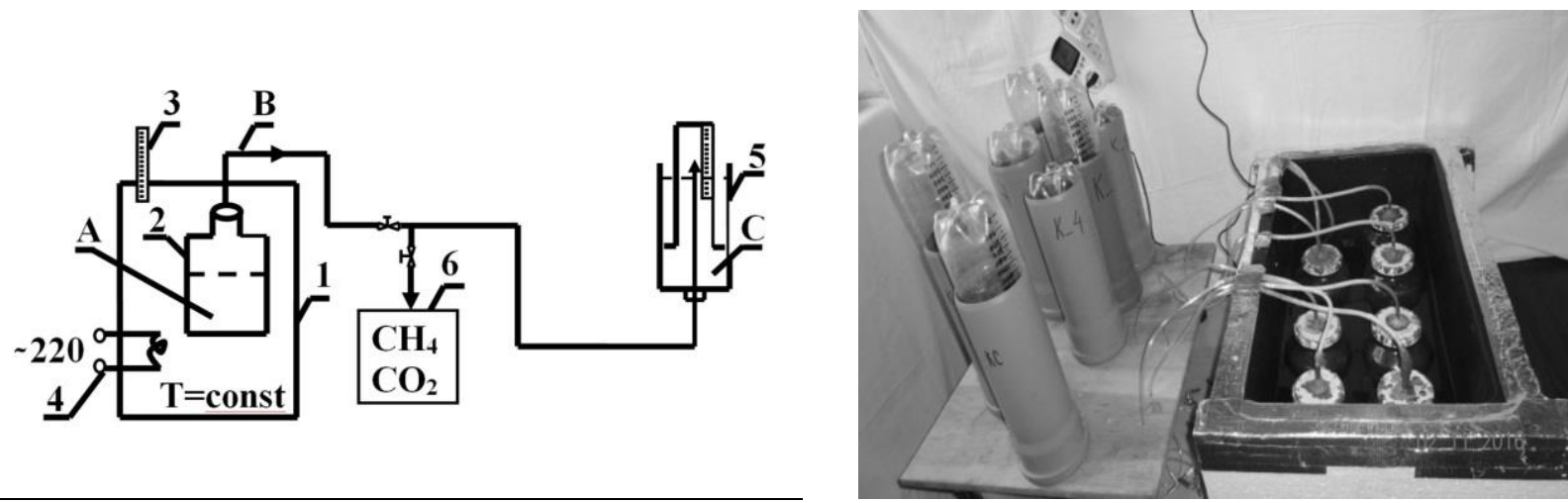

Рис. 3. Схема і фото лабораторної установки:

1 - термостат, 2 - реактори, 3 - ртутний термометр, 4 - електричний нагрівач з регулятором температури, 5 - газгольдери, 6 -газоаналізатор, $\mathrm{A}$ - субстрат, $\mathrm{B}$ - біогаз, $\mathrm{C}$ - розчин $\mathrm{NaCl}$.

Fig. 3. Scheme and photo of the laboratory setup:

1 -thermostat, 2 - reactors, 3 -mercury thermometer, 4 - electric heater with temperature regulator 5 - gasholders, 6 - gas analyzer, A-substrate, $\mathrm{B}$ - biogas, $\mathrm{C}-\mathrm{NaCl}$ solution.

Установка складається з термостату, в якому розміщено три реактора, ртутний термометр та терморегулятор. Термостат теплоізольований та наповнений водою. Газгольдери герметично з'єднані з реакторами трубками. Нерухома частина газгольдерів виставлена горизонтально та заповнена 5-\% розчином $\mathrm{NaCl}$ для запобігання розчинення вуглекислого газу у воді. На рухомій частині газгольдерів нанесені відмітки для визначення об'єму біогазу.

Реактори мали загальний об' $€$ м 1,5 дм $^{3} \quad 3$ об'ємом субстрату 1,05 дм³. Максимальний об'єм газгольдера $-2,0$ дм $^{3}$. Для створення анаеробних умов в реакторі газовий простір системи реактор- газгольдер безпосередньо перед початком експерименту продували азотом, об'єм якого був в три рази більший за об'єм вказаного газового простору.

Експеримент був проведений за мезофільного режиму. Температура в термостаті підтримувалась на рівні $35,5 \pm 0,2^{\circ} \mathrm{C}$.

Було підготовлено три субстрати. Один із них, контрольний субстрат, містив коров'ячий гній, інокулят та воду (БВ-0). Два інших - містили коров'ячий гній, інокулят, воду та біовугілля. Для субстрату (БВ-СС) було взято біовугілля із стебел соняшника, а для (БВ-ДТ) - біовугілля із деревної тріски. Біовугілля вносили по 25 г. На рис. 4 зображені фото біовугілля.
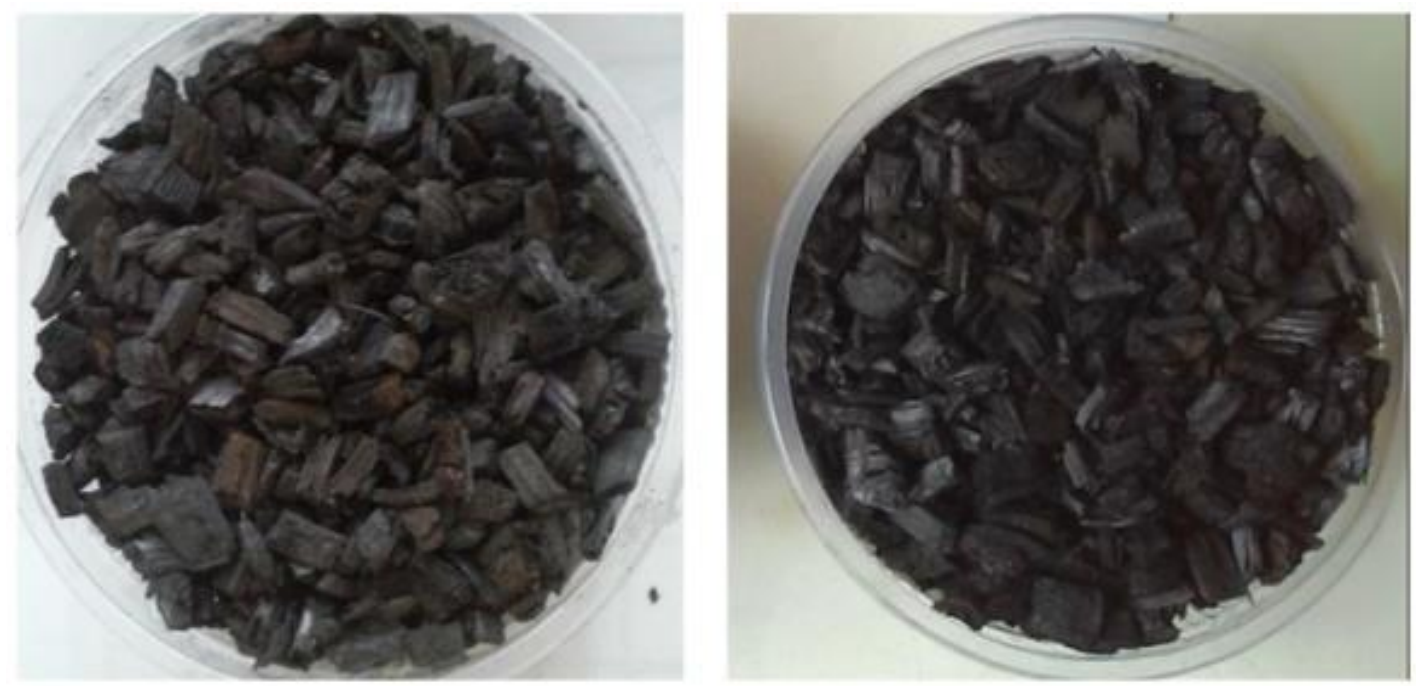

Рис. 4. Біовугілля:

зліва - із стебел соняшника, справа - із деревної тріски.

Fig. 4. Biochar:

on the left-from sunflower stalks, on the right-from wood chips. 
Вміст коров'ячого гною та інокуляту в субстратах підбирали так, щоб значення сухого органічної речовини коров'ячого гною та інокуляту було рівним. За таких умов виключалось інгібування бродіння леткими жирними кислотами [12]. Субстрати разбавляли водою до вологості $97 \%$.

Інокулят попередньо був адаптований до досліджуваного субстрату і умовам бродіння. Значення вмісту сухої речовини в субстраті та значення вмісту золи у сухому залишку вимірювали стандартним гравіметричним методом [13].

Об'ємну концентрація $\mathrm{CO}_{2}$ в біогазі визначали хімічним газоаналізатором «ГХЛ». Окремі аналізи біогазу на $\mathrm{CO}_{2} \mathrm{i} \mathrm{CH}_{4}$ виконували на портативному цифровому газоаналізаторі «Landtec».

Проведені дослідження показали, що за присутності деяких видів біовугілля відбувається підвищення виходу біогазу. На 56-у добу бродіння було отримано $2,53 \mathrm{дм}^{3} / \mathrm{дм}^{3} ; 2,73 \mathrm{дм}^{3} /$ дм$^{3}$ i $2,9 \mathrm{дм}^{3} / \mathrm{дм}^{3}$ біогазу при переробці субстратів БВ-0; БВ-ДТ та БВ-СС відповідно. Отже, вихід біогазу із субстратів, що містили біовугілля підвищився на 7,9-14,6 \% у порівнянні з контрольним субстратом.

На рис. 5 наведено куммулятивний вихід біо-

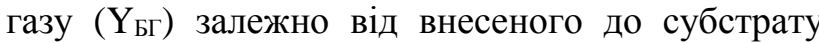
виду біовугілля.

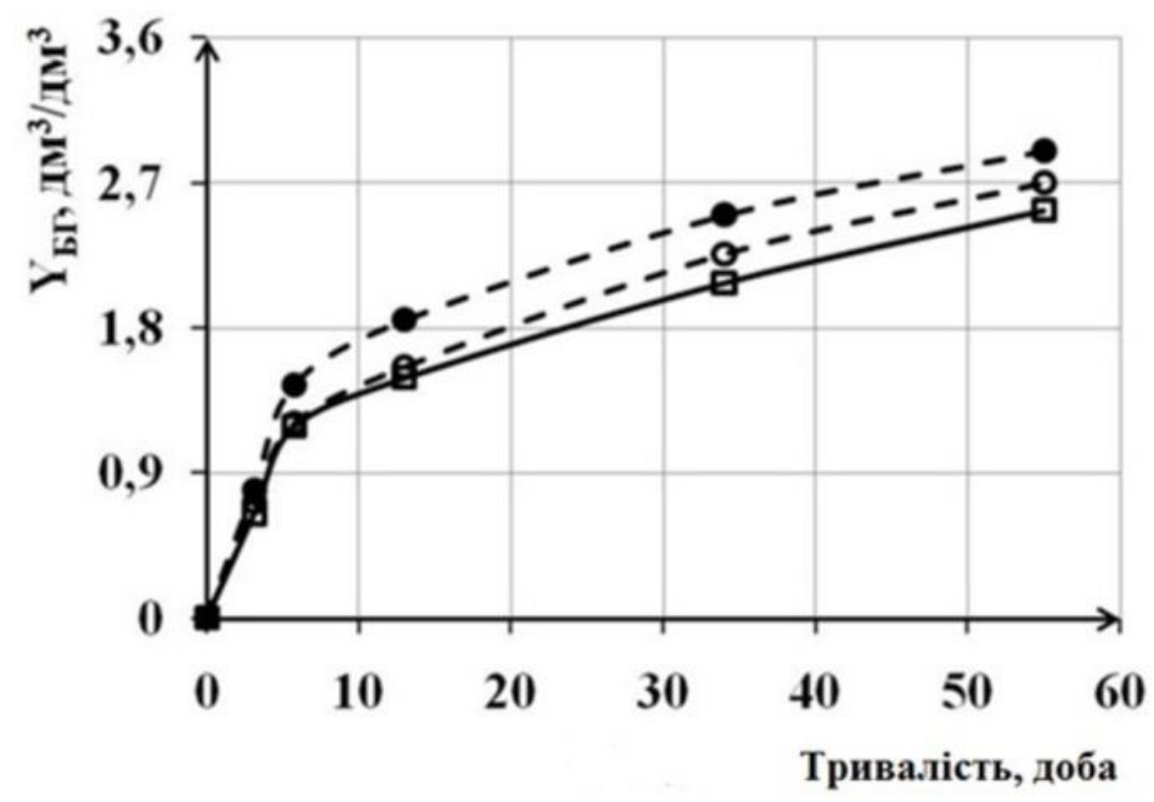

Рис. 5. Куммулятивний вихід біогазу: $\square-Б B-0, \bullet-Б B-C C, \circ-Б B-Д T$.

Fig. 5. Cumulative biogas yield:

$\square-$ control sybstrate, without biochar, $\bullet-$ sybstrate with biochar from sunflower stalks, ○- sybstrate with biochar from wood chips.

Визначення показників процесу отримання біогазу. Процес отримання біогазу залежить від біогазового потенціалу, яким володіє підготовлений субстрат і характеризується такими показниками як максимальна інтенсивність виходу біогазу та тривалість лаг-фази. Біогазовий потенціал субстрату залежить від складу вихідної сировини (співвідношення між білками, жирами та вуглеводами). Максимальна інтенсивність виходу біогазу залежить від швидкості зростання мікробних популяцій. Лаг-фаза це період часу, за який мікробні популяції здатні адаптуватися до нового середовища та до живильних речовин субстрату.

Для визначення вказаних показників процесу утворення біогазу візьмемо відому залежність
Гомпертца, яка описує динаміку виходу біогазу $[8,12]$

$$
\mathrm{Y}_{Б \Gamma}(\tau)=\mathrm{P} \cdot \exp \left(-\exp \left(\frac{\mathrm{I}_{\max } \mathrm{e}(\mathrm{L}-\tau)}{\mathrm{P}}+1\right)\right) .
$$

Показники процесу утворення біогазу з коров'ячого гною було визначено шляхом апроксимації кривої (1) до отриманих експериментальних даних. Константи в залежності (1) визначено методом наймених квадратів за допомогою комп'ютерної програми, реалізованої в MathCad. В табл. 1 наведено отримані показники полученные показатели процесу утворення біогазу з коров'ячого гною. 
Таблиця 1. Показники процесу утворення біогазу.

Table 1. Indicators of biogas production process.

\begin{tabular}{|c|c|c|c|}
\hline Субстрат & $\mathrm{I}, \mathrm{cm}^{3} / \Gamma$ СОР·доба & $\mathrm{L}$, доба & $\mathrm{P}, \mathrm{cm}^{3} / \Gamma$ COP \\
\hline БВ-0 & 119,9 & 0,55 & 2790 \\
\hline БВ-ДТ & 141,2 & 0,48 & 2790 \\
\hline БВ-СС & 200,4 & 0,33 & 2790 \\
\hline
\end{tabular}

Аналогічно визначали показники процесу утворення біогазу з коров'ячого гною в присутності різних видів біовугілля (див. табл. 1). Як бачимо, вихід біогазу збільшився за рахунок збільшення максимальної інтенсивності виходу біогазу та зменшення тривалості лаг-фази.

Склад біогазу, отриманого із субстратів БВ0; БВ-ДТ и БУ-СП був наступний: $39,2 \% \mathrm{CO}_{2}$, $58,8 \% \mathrm{CH}_{4} ; 39,7 \% \mathrm{CO}_{2}, 58,3 \% \mathrm{CH}_{4} ; 40,6 \% \mathrm{CO}_{2}$, $57,4 \% \mathrm{CH}_{4}$ відповідно. Вміст інших газів (крім $\mathrm{CO}_{2}$ i $\mathrm{CH}_{4}$ ) в біогазі не перевищувало $2 \%$.

Враховуючи вихід біогазу та його склад маємо, що вихід метану при переробці субстратів, що містили біовугілля підвищився на 6,7-11,4 \% в порівнянні $з$ контрольним субстратом.

Отже, визначено види біовугілля, які сприяють інтенсифікації процесу бродіння. Біовугілля було отримане способом часткової газифікації стебел соняшнику та деревної тріски. Вихід біогазу підвищився на 7,9-14,6 \% і вихід метану підвищився на 6,7-11,4 \% під час бродіння субстратів, до яких вносили біовугілля у порівнянні 3 контрольним субстратом. Підвищення виходу біогазу приводить до підвищення енергоефективності перетворення органічних речовин в біогаз.

Висновки: 1. Розроблено конструкції біогазового реактора з мокрим газгольдером, в яких для перемішування субстрату використовується вироблений біогаз.

2. Експериментально досліджено як впливає на вихід біогазу внесення до коров'ячого гною біовугілля, яке отримане способом часткової газифікації стебел соняшнику та деревної тріски. Показано, що внесення біовугілля до субстрату сприяє інтенсифікації процесу бродіння.

1. Susse L. Biogas plants - design and detail of simple biogas plants. Bremer. $1988.85 \mathrm{p}$.

2. Kuria J., Maringa M. Development simple procedures for selecting, sizing, scheduling of materials and costing of small biogas units. International Journal for Service Learning in Engineering. 2008. Vol. 3. No. 1. Pp. 9-40.

3. Khoiyangbam G., Kumar S., Jain M. Methane losses from floating gasholder type biogas plants in relation to global warming. Journal of Scientific and Industrial Research. 2004. Vol. 63. Pp. 344-347.

4. Werner U., Stöhr U., Hees N. Biogas plants in animal husbandry - a practical guide. Friedr. Vieweg and Sohn. Braunschweig.Wiesbaden. 1989. 153 p.
5. Lehman J., Kyzyakov Y., Pan G., Ok Y. Biochars and the plant-soil interface. Plant and Soil. 2015. Vol. 395. Pp. 1-5.

6. Tambone F., Scaglia B., D’Imporzano G., Schievano A., Orzi V., Salati S., Adani F. Assessing amendment and fertilizing properties of digestates from anaerobic digestion through a comparative study with digested sludge and compost. Chemosphere. 2010. Vol. 81. Pp. 577-583.

7. Cai J., He P., Wang Y., Shao L., Lu F. Effects and optimization of the use of biochar in anaerobic digestion of food waste. Waste Manag. Res. 2016. No. 5. Pp. 409-416.

8. Angelidaki I., Ellegaard L., Ahring B.K. A mathematical model for dynamic simulation of anaerobic digestion of complex substrates. Focusing on ammonia inhibition. Bioresource Technology. 1993. No. 42. Pp. 159-166.

9. Koster I.W., Lettinga G. Anaerobic digestion at extreme ammonia concentrations. Biol. Wastes. 1988. Vol. 25. Pp. 51-59.

10. Sung S., Liu T. Ammonia inhibition on thermophilic anaerobic digestion. Chemosphere. 2003. Vol. 53. Pp. 43-52.

11. Yoshida H., Tokumoto H., Nishiguchi R. Improvement of anaerobic digestion using immobilization methanogens. [Електронний pecypc]. URL: https://www.jstage.jst.go.jp/article/apcche/2004/0/2004_0 _854/_pdf. (дата звернення: 12.06.2019).

12. Zvietering M., Jongenburger I., Rombouts F., Vant Riet $K$. Modeling of the bacterial growth curve. Applied and Environmental Microbiology. 1990. No. 56. Pp. 1875-1881.

13. ДСТУ ЕN 12048:2005. Добрива тверді та вапнувальні матеріали. Визначення вмісту вологи гравіметричним методом. Висушування за температури $105 \pm 2^{\circ} \mathrm{C}$. К. Держспоживстандарт. України. 2006.

\section{REFERENCES}

1. Susse L. Biogas plants - design and detail of simple biogas plants. Bremer. 1988. 85 p. [in English].

2. Kuria J., Maringa M. Development simple procedures for selecting, sizing, scheduling of materials and costing of small biogas units. International Journal for Service Learning in Engineering. 2008. Vol. 3. No. 1. Pp. 9-40. [in English].

3. Khoiyangbam G., Kumar S., Jain M. Methane losses from floating gasholder type biogas plants in relation to global warming. Journal of Scientific and Industrial Research. 2004. Vol. 63. Pp. 344-347. [in English].

4. Werner U., Stöhr U., Hees N. Biogas plants in animal husbandry - a practical guide. Friedr. Vieweg and Sohn. Braunschweig.Wiesbaden. 1989. 153 p. [in English].

5. Lehman J., Kyzyakov Y., Pan G., Ok Y. Biochars and the plant-soil interface. Plant and Soil. 2015. Vol. 395. Pp. 1-5. [in English].

6. Tambone F., Scaglia B., D'Imporzano G., Schievano A., Orzi V., Salati S., Adani F. Assessing amendment and fertilizing properties of digestates from anaerobic digestion through a comparative study with digested sludge and compost. Chemosphere. 2010. Vol. 81. Pp. 577-583. [in English].

7. Cai J., He P., Wang Y., Shao L., Lu F. Effects and optimization of the use of biochar in anaerobic digestion of food waste. Waste Manag. Res. 2016. No. 5. Pp. 409-416. [in English].

8. Angelidaki I., Ellegaard L., Ahring B.K. A mathematical model for dynamic simulation of anaerobic digestion of complex substrates. Focusing on ammonia inhibition. Bioresource Technology. 1993. No. 42. Pp. 159-166. [in English].

9. Koster I.W., Lettinga G. Anaerobic digestion at extreme ammonia concentrations. Biol. Wastes. 1988. Vol. 25. Pp. 51-59. [in English].

10. Sung S., Liu T. Ammonia inhibition on thermophilic anaerobic digestion. Chemosphere. 2003. Vol. 53. Pp. 43-52. [in English]. 
11. Yoshida H., Tokumoto H., Nishiguchi R. Improvement of anaerobic digestion using immobilization methanogens. [Electronic resource]

URL: https://www.jstage.jst.go.jp/article/apcche/2004/0/2004_0 854/_pdf. (Applying date: 12.06.2019). [in English].

12. Zvietering M., Jongenburger I., Rombouts F., Vant Riet $K$. Modeling of the bacterial growth curve. Applied and Environmental Microbiology. 1990. No. 56. Pp. 1875-1881. [in English].

13. DSTU EN 12048:2005. Dobryva tverdi ta vapnuval'ni materialy. Vyznachennya vmistu volohy hravimetrychnym metodom. Vysushuvannya za temperatury $105 \pm 2{ }^{\circ} \mathrm{C}$. [State Standard EN 12048:2005. Fertilizers for solid and lime materials. Determination of moisture content by gravimetric method. Drying at $\left.105 \pm 2{ }^{\circ} \mathrm{C}\right]$. State Committee of Ukraine for Technical Regulation and Consumer Policy Publ. Kyiv. 2006. [in Ukrainian].

\section{ПОВЫШЕНИЕ ЭНЕРГЕТИЧЕСКОЙ ЭФФЕКТИВНОСТИ БИОГАЗОВЫХ РЕАКТОРОВ}

В.П. Клюс, канд. техн. наук, Г.А. Четверик, канд. техн. наук, 3.В. Маслюкова

Институт возобновляемой энергетики НАН Украины, 02094, ул. Гната Хоткевича 20А, г. Киев, Украина.

Для небольших фермерских хозяйств актуальным является переработка органических отходов в энергоэффективных биогазовых реакторах. Целью работы является повышение энергоэффективности биогазовых реакторов. Разработаны две новые конструкиии биогазового реактора, которые отличаются от известных конструкиий тем, что в них преобразования поступательного движения газгольдера во вращение перемешивающего устройства обеспечивается за счет использования механизма с зубчато-реечной передачей и механизма с канатной тягой соответственно. При этом для перемешивания субстрата используется произведенный биогаз, который накапливается в газгольдере. Показано, что энергоэффективность биогазовых реакторов с мокрым газгольдером повышается путем снижения энергетических затрат на поддержание проиесса брожения. Предложенные конструкиии реакторов можно использовать при проектировании новых и усовершенствование существующих биогазовых реакторов с мокрым газгольдером. Проведен эксперимент с анаэробного брожения коровьего навоза, в который вносили биоуголь, полученное способом частичной газификачии стеблей подсолнечника и древесной щепь. Определено, что выход биогаза повысился на 7,9-14,6\% и выход метана повысился на 6,7-11,4\% во время брожения субстратов, с которыми вносили биоуголь по сравнению с контрольным субстратом. Определена максимальная интенсивность выхода биогаза и продолжстельности лаг-фазы во время брожения коровьего навоза, в том числе и с внесенным $\kappa$ коровьему навозу биоуглем. Показано, что энергоэффективность биогазовых реакторов с мокрым газгольдером повышается путем интенсификачии прочесса брожения. Предложенные виды биоугля можно использовать для интенсификации процесса брожения. Библ. 13 рис. 5.

Ключевые слова: биореактор, биогаз, иммобилизация, устройство для перемешивания, биоуголь.

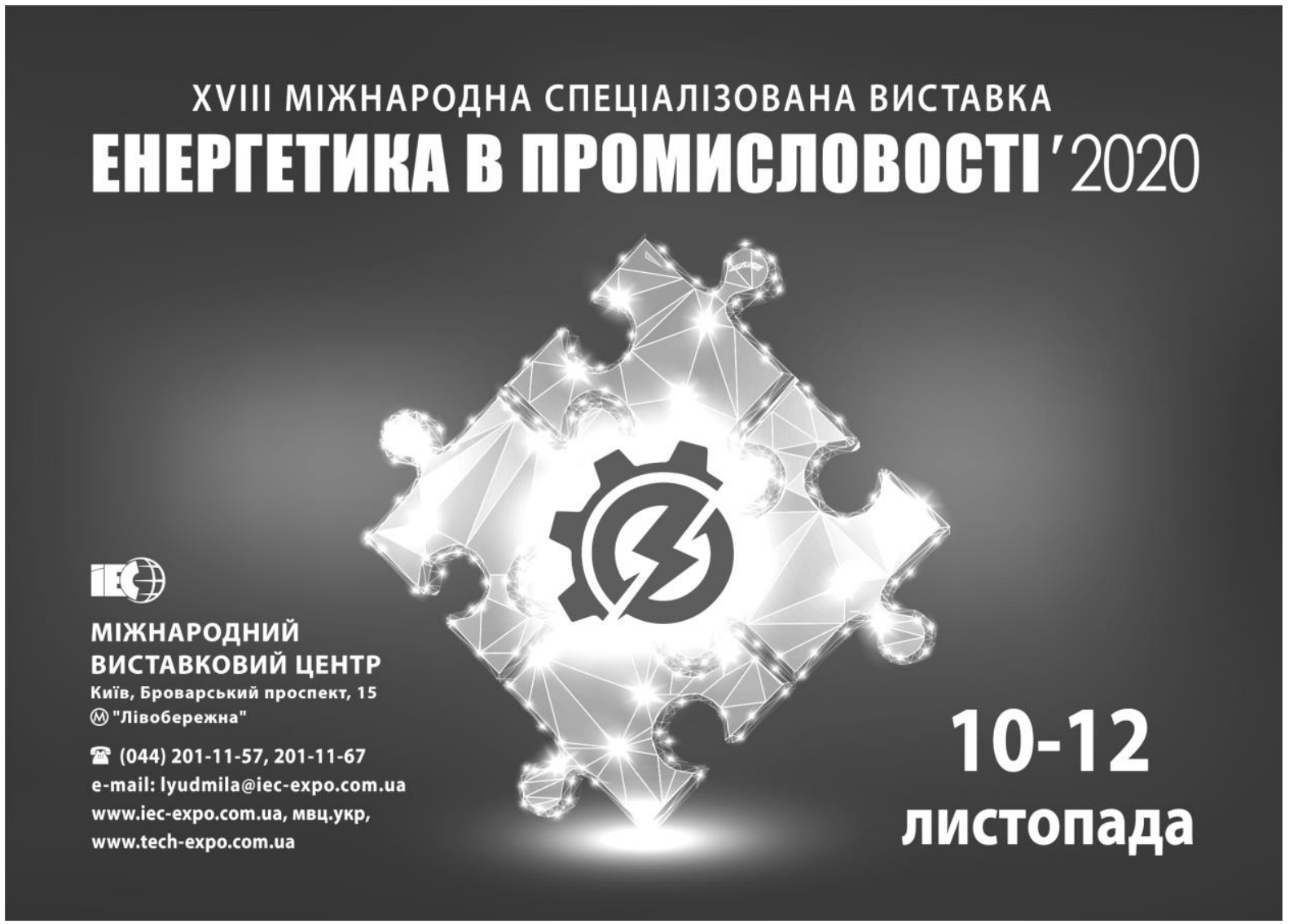

